\title{
Homestay save rent method through consumer self- management of electricity power consumption
}

\author{
Dirman Hanafi', Kamal Khairi Kamaruddin², Hisyam Abdul Rahman ${ }^{3}$, Yudhi Gunardi ${ }^{4}$ \\ 1,2,3 Instrumentation and Sensing Technology (InSeT) Research Group, Faculty of Electrical and Electronic Engineering, \\ Universiti Tun Hussein Onn Malaysia, Malaysia \\ ${ }^{4}$ Department of Electrical Engineering, Universitas Mercu Buana, Indonesia
}

\begin{tabular}{l}
\hline \hline Article Info \\
\hline Article history: \\
Received Aug 18, 2019 \\
Revised Oct 12, 2019 \\
Accepted Nov 29, 2019 \\
\hline
\end{tabular}

Keywords:

Homestay

Expensive

Electricity

Self-management

Coin kilowatt hour meter

\begin{abstract}
The rapid growth in the number of homestays and hotels, competition has increased among them. Homestay that is a relatively newcomer in this business should find the way to become competitive. One way is to make rental fees more affordable. In this paper a method to reduce the homestay rental fees are proposed. This is done by separating the component of the electricity cost from the whole rental fees. Then it requires the consumer to pay their own electricity used and also gives opportunity to them to manage their own electricity used how much they need. This mechanism is implemented by equipping the homestay with the coin kilowatt hour (ckWh) meter. The consumer can plan how much they will use the power since they stay by inserting the certain amount of coin into the ckWh meter. After insert the coin the electricity sources will on and ready to use. The main components of this ckWh meter consist of the Arduino Uno microcontroller as a brain of the device, the coin acceptor where the coin will insert, and kilowatt hour meter. Besides that, it also equipped with liquid-crystal display (LCD) to show the amount of money currently available. The experimental test shows that the device develop work well and can control the used of the electricity related to the amount money that has been inserted.
\end{abstract}

This is an open access article under the CC BY-SA license.

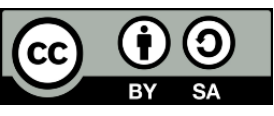

\section{Corresponding Author:}

Dirman Hanafi,

Instrumentation and Sensing Technology (InSeT) Research Group,

Faculty of Electrical and Electronic Engineering,

Universiti Tun Hussein Onn Malaysia, 86400 Parit Raja, Johor, Malaysia.

Email: dirman@uthm.edu.my

\section{INTRODUCTION}

The Malaysia among the top 10 countries receives foreign tourists every year. This high volume is closely related to Malaysia's diversified tourism products. Among the products being developed are homestay [1]. Homestay businesses grow rapidly not only in the city but till to the village. The main purpose is for tourism, university areas and stay at village program. Based on statistic by Ministry Tourism and Culture of Malaysia, 5604 rooms of 203 homestays have been registered and the possibility of this amount will increase [2-4]. According to reports from the Minister of Tourism, Arts and Culture Minister Datuk Mohammadin Ketapi said there were 8.47 million who came to Malaysia in 2018, some of them chose to live in homestays. This numbers continue to increase every year, providing well opportunities for the homestay business [2-8].

There are several logic reasons why the visitors prefer homestay for accommodation, among other: comfort factor, safety factor, wider space, flexible check-in time, strategic location, unique design, there are many basic amenities under one roof, more privacy and no need to share, it feels like home, can provide your own food and etc [4]. Along with the rapid growth of homestays, at present hotel entrepreneurs have begun to 
expand their business to remote areas. Of course this will be other rival for the homestay beside rivalled by themselves [9]. For this condition the homestay should look any other way to promote and attract customers. One way is by minimizing the rent fees. Usually customers will look at the rent fees and facilities first before making their choices and booking $[10,11]$.

There are several electrical equipment provided to provide consumers comfort in a rental house, including lights, television, rice cooking utensils, refrigerators, air conditioners, washing machines, electric stoves, etc. Sometimes due to forgetfulness, consumers forget to turn off the equipment when they want to sleep or also leave any needs. So that it causes waste of electricity use. In order to cover the expenditure of electricity consumption, the fees usually includes in to the fees of the homestay rental. Furthermore, rental prices will be expensive, so that make the homestay business is less competitive. Therefore, the electricity consumption cost should separating from total rental fees. The rent fees become cheaper and the homestay business become more competitive. Consumers are required to manage and pay how much they want to consume the electricity [12-16]. If consumers want to minimize their electricity usage they can manage the number and time of the appliances on [14-19].

For this purpose, in this work the homestay is equipped with the coin kilowatt hour (ckWh) meter device. To turn on the power source, a number of coins must be inserted into the ckWh meter. The total number of coins entered will be proportional to the length of time the electricity resources on [20-22]. This means that for a number of coins that have been entered, if the amount of load is reduced the electricity resources on will be longer and vice versa will be shorter. The type of coins that can be used is 1 ringgit, 50 cents, 20 cents and 10 cents. The payment rate for electricity bills is RM 0,281/kWh following the electricity rates used by Tenaga Nasional Berhad (TNB) $[23,24]$. Then this level of payment will follow changes during the time set by TNB. The total amount of money available and also the use of electric power per hour will be shown to consumers using liquid-crystal display (LCD) [21].

This paper consisted of three sections. Section one explains about introduction about the problem that will overcome. The second section explains how the problem is solved in detail. The second section explains the methodology used to solve the problem in detail. Starting from designing the equipment to be made, explaining the functions and testing the performance of each components and finally fabricate equipment. The last section elaborates the equipment test results and analysis to determine whether it meets the objectives.

\section{RESEARCH METHOD}

Methodology is defined as systematic step by step to solve the problem in order to achieve the objectives. The steps include the design, implementation and test.

\subsection{System design}

System design in the form of block diagrams will show each sub-block that represents its function in the system as a whole. Figure 1 shows the block diagram of coin kilo Watt meter developed.

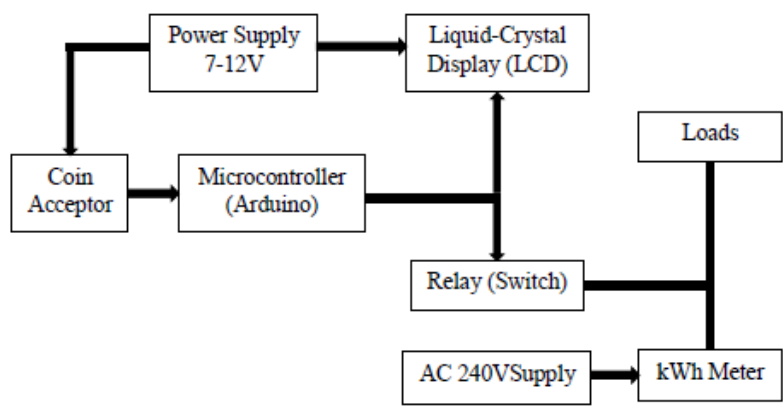

Figure 1. Block of the coin kilo Watt hour (ckWh) meter

The main component of ckWh meter is an Arduino Uno microcontroller as a brain of this device [25]. It has a function to control all the sub-components such as coin acceptor, liquid-crystal display (LCD),

Int J Pow Elec \& Dri Syst Vol. 11, No. 1, Mar 2020 : 425 - 432 
kilowatt hour meter (kWh Meter) and relay. All control commands are compiled in programming code. The flowchart how the system work is shown by Figure 2 below.

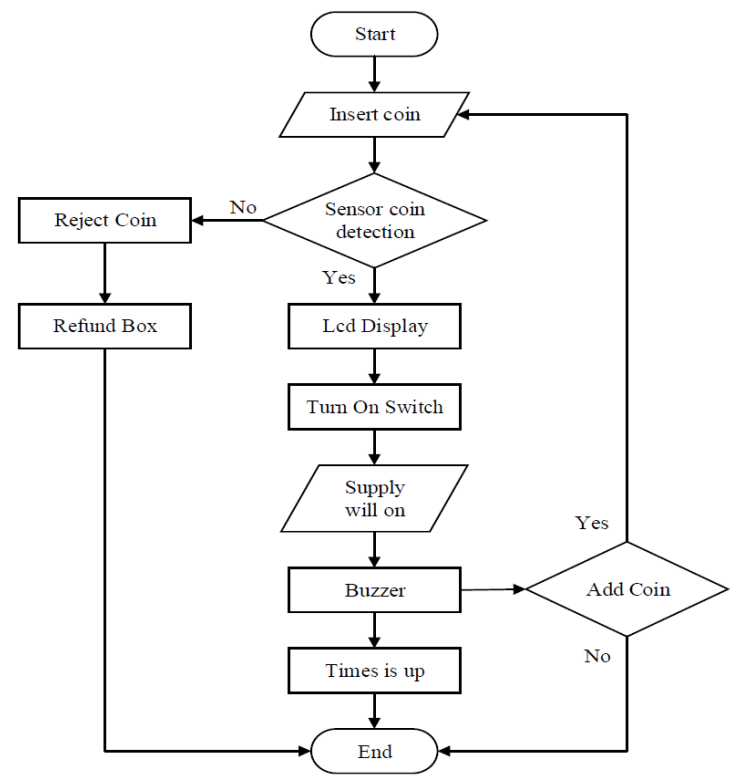

Figure 2. System operation flow chart

\subsection{Coin aceptor}

The coin acceptor device is a module which detects and counts the number of coin and then sends the signal to the Arduino board [20,21]. The accepted coins consist of four types, they are 1 ringgit 50 cent, 20 cent and 10 cent. The coin acceptor has a function for inserting coins. The total amount of coins that have been entered will be processed by Arduino to determine the amount in the form of money and show it on the LCD display. Then the Arduino will send signal to the relay to close the contactor in order to on the electricity source.

\subsection{Coin aceptor component}

The microcontroller used in this work is Arduino Uno. Where this type of microcontroller board is based on the ATmega328P. It has 14 digital input or output pin ports which 6 can be used as PWM outputs, a USB connection, a power jack, an ICSP header and a reset button. In order to get it started, it is essential to simply connect it to a computer with a USB cable or power it with an AC-to-DC adapter or battery [25].

Arduino will receive the signal from the coin acceptor as described earlier. The signal will be processed, the first is to determine the amount of the total coins that have been insert in form of money and display it on the LCD display. Second is to send the command to the relay to close the contactor and display on the LCD that the power source has been on and ready to use. Furthermore, if the consumer connects an equipment with an electric power source, Arduino will calculate the total power of the equipment and determine how long it will be available to allow the contactor to connect and display on the LCD screen. At that time, if consumers reduce or increase the number of equipment or loads connected, at the same time Arduino will recalculate the length of time the contactor can on and shows it in the LCD screen.

\subsection{Liquid-crystal display (LCD)}

Type of LCD use is $16 \times 2$ LCD display. Its name is based on it has 16 Columns and 2 Rows. This type is fulfill the requirement of the device developed. Figure 3 shows the physical form of LCD.

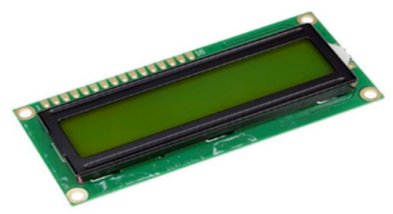




\subsection{Relay}

Figure 3. Liquid-crystal display (LCD)

The function of the relay is to open or close the circuit connection between ckWh meter and the loads. When the Arduino detects any amount of coin (money), it sends the signal to relay to close the contactor. After the time on of contactor based on the Arduino calculation has been reached, then Arduino sends signal to relay to open the contactor.

\subsection{Kilowatt hour meter (kWh Meter)}

Kilowatt hour meter is the one important component in this device [23,24]. It has functions to determine the energy usage and display it. The type of the $\mathrm{kWh}$ meter is a pulse type, it means the power used in hour is counted through pulse. The total power per hour for one pulse $(u)$ is determined using Equation. (1) to (4) below:

$$
\begin{aligned}
& p=\left(p_{\_} r \times W \times t\right) \div(1000 \times 3600) \\
& t \_p=p \times t \\
& P F=W \div t_{-} p \\
& u=\left(P F \times t_{-} p\right) \div 1000
\end{aligned}
$$

Where: $p$ is pulse, $p_{-} r$ is pulse rate, $W$ is power, $t$ is time, $t_{-} p$ is total pulse, and $P F$ is prorate factor. The specification of the kilo Watt hour meter used in this study is elaborated in Table 1.

Table 1. Specification of kilo watt hour meter

\begin{tabular}{cc}
\hline Nominal voltage (Un) & $120 / 230 \mathrm{AC}$ \\
\hline Operational voltage & $84-156 \mathrm{~V} \mathrm{AC} / 161-300 \mathrm{~V} \mathrm{AC}$ \\
Basic current (Ib) & $5 \mathrm{~A} / 10 \mathrm{~A} / 20 \mathrm{~A}$ \\
Maximum rated current (Imax) & $60 \mathrm{~A} / 63 \mathrm{~A} / 100 \mathrm{~A}$ \\
Operational current range & $0.04 \mathrm{~A}-60 \mathrm{~A} / 0.08 \mathrm{~A}-100 \mathrm{~A}$ \\
Over current withstand & $1800 \mathrm{~A} / 3000 \mathrm{~A}$ for $0.01 \mathrm{~s}$ \\
Operational frequency range & $50 / 60 \mathrm{~Hz} \pm 10 \%$ \\
Internal power consumption & $\leq 2 \mathrm{~W} / 10 \mathrm{VA}$ \\
Test output flash rate (RED LED) & 500 impulses per kWh \\
Backlit LCD display & $7+1$ digits \\
Data save & 20 years \\
Maximum cable capacity & $25 \mathrm{~mm} 2$ \\
\hline
\end{tabular}

\subsection{Coin Kilowatt Hour Meter}

The combination of several components that have been described previously formed a prototype of a coin kilowatt hour (ckWh) meter. Based on the circuit connection the prototype of ckWh meter is fabricated. Where the top view and front view of the prototype of ckWh meter are shown by Figure 4. To run this equipment it is necessary to have a program in the form of a list of commands which covers how each component's work, coordination of each component and the working sequential of each component. This list of commands will be embedded in the Arduino boards that function as the brain of ckWh meters.

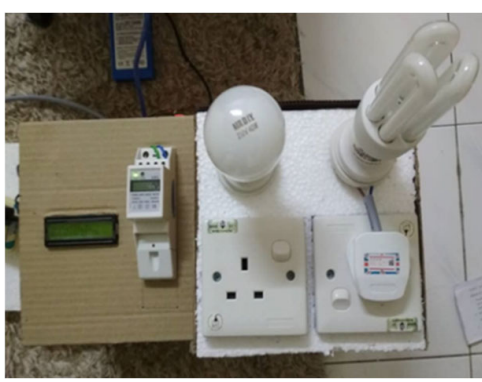

(a)

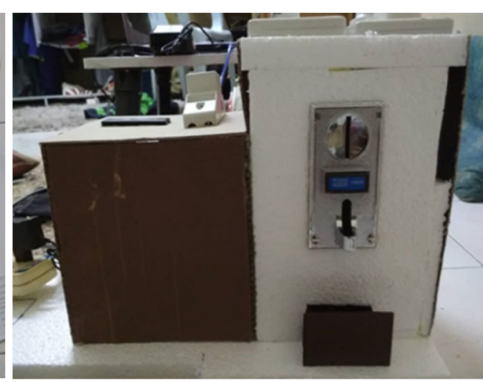

(b)

Figure 4. Prototype coin kWh meter, (a) top view, (b) front view 


\section{RESULTS AND DISCUSSION}

In this section, it is explained the results of research and at the same time is given the comprehensive discussion. Results can be presented in figures, graphs, tables and others that make the reader understand easily $[2,7]$. The discussion can be made in several sub-chapters.

\subsection{Power consumption estimation and total billing}

Firstly, to estimate the total amount of loads in homestay. The loads can be electrical appliances and components such as fluorescent lamp, ceiling fan, ventilating fan, air-conditional, water heater and some socket outlet. Furthermore, the total load will be calculated to determine the maximum demand. From this data, it can be calculated the total hourly energy consumption with equation. (5):

$$
E_{T}=P_{\max } \times \mathrm{D} \times \mathrm{H}
$$

Were: $E_{T}$ is total energy per hour, $P_{\max }$ is maximum demand, $\mathrm{D}$ is number of day and $\mathrm{H}$ is hour.

One of the homestays in Parit Raja area, Batu Pahat Johor Malaysia has been taken as a sample in this study. The unit of electrical appliances and components is assume based on normal semi-detached house 3 rooms. The estimation of total energy consumption is $486 \mathrm{kWh}$ for 5 days. The electrical bill is calculate automatically based on tariff from TNB standard [19, 24, 25] and obtained total bill for 5 days is RM 125.60. The total bill have been calculated at maximum energy consumption. The bill can reduce if the users reduce electricity consumption. The summary of energy demand for minimum, average and maximum based on 5 different type of houses that have supply from the utilities company are shown in Table 2.

Table 2. Summarises of energy demand

\begin{tabular}{ccccc}
\hline No & Type of houses & Minimum $(\mathrm{kW})$ & Average $(\mathrm{kW})$ & Maximum $(\mathrm{kW})$ \\
\hline 1 & Low cost flats, single storey terrace & 1.5 & 2.0 & 3.0 \\
2 & Double storey terrace or apartment & 3.0 & 4.0 & 5.0 \\
3 & Single storey, semi-detached & 3.0 & 5.0 & 7.0 \\
4 & Single storey bungalow \& three-room condominium & 5.0 & 7.0 & 10.0 \\
5 & Double storey bungalow \& luxury condominium & 8.0 & 12.0 & 15.0 \\
\hline
\end{tabular}

\subsection{Coin acceptor precision performance test}

Coin acceptor have their own number of precision form number 1 to 25 to detect the types of coin when insert into the slit [22]. The smaller the number, the more accurate the precision but the suggestion in manual is number 8 . Only 4 testing which is the selected number precision are number 1 , number 8 , number 16 and number 25 with 6 difference coins for 20 times. Figure 5 represents the coin acceptor test result. The results have taken from the serial monitor in Arduino software. To run the serial monitor, the Arduino board should connected with the computer using Universal Serial Bus (USB) and compiled into the Arduino board.

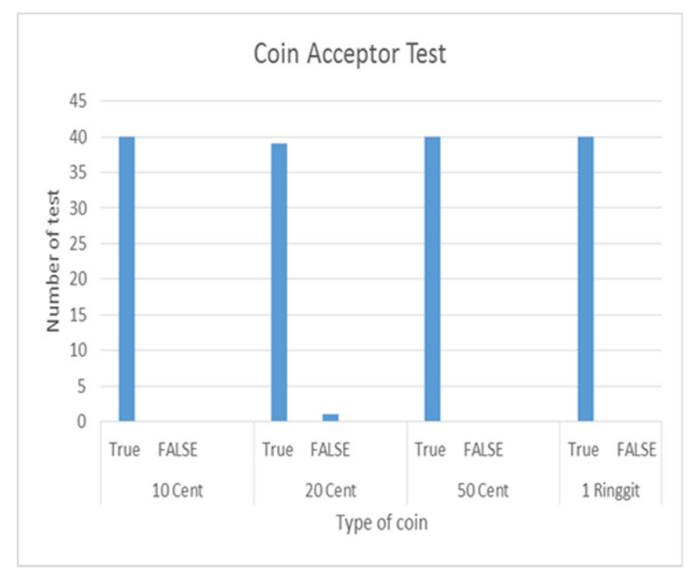

Figure 5. Coin acceptor test 
The table above shows that only 1 time the false occurred by the coin acceptor in determining the type of coin entered. Trials for each type of coin are carried out 40 times. The false is happen for 20 cents coin type $(2.5 \%)$. While for other types of coins, $100 \%$ coin acceptors can detect correctly. The error may occur due to the existence of two different sizes for 20 cents coins. Where the new 20 cents coin has a smaller size compared to the old 20 cents coin.

\subsection{Unit and balance}

The unit is a unit to state the amount of energy available according to the amount of money (Ringgit Malaysia) that has been entered into the coin acceptor. While balance indicates the amount of money currently available. The data shown by Figure 6 is the data changing, including the remaining money for each one pulse increases.

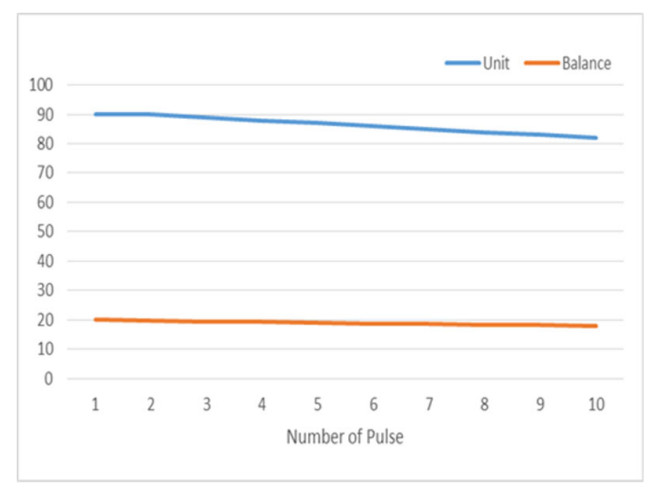

Figure 6. Unit and balance for each one pulse increases

Above data is acquired for 18 minutes testing time with 55 watt load, 500 pulse rate of $\mathrm{kWh}$ meter and 20 cents initial balances.

\subsection{Comparison between test result and calculation result}

Calculation below shows the values of unit and balance in 18 minutes according to the data that have been taken.

$$
\begin{aligned}
\text { pulse } & =(\text { pulse ratexwattxtime }) \div(1000 \times 3600) \\
& =(500 \times 55 \times 60) \div(1000 \times 3600) \\
& =0.5 \text { per } \min
\end{aligned}
$$

Based on pulse per min previous calculation result, it means for 18 minutes time load supply the total pulse is 9 as below:

$$
\begin{aligned}
\text { total pulse in } 18 \mathrm{~min} & =\text { pulse } \times \text { time taken }(t) \\
& =0.5 \times 18 \mathrm{~min} \\
& =9 \text { pulses }(\text { led blinking })
\end{aligned}
$$

Then, the number of unit is

$$
\begin{aligned}
\text { unit } & =(P F \times \text { total pulse }) \div 1000 \\
& =(2 \times 9) \div 1000=0.018
\end{aligned}
$$

Tariff should be paid for 18 minutes use of 55 watt load is

$$
\begin{aligned}
\text { bill }(\text { cents }) & =\text { unit } \times \text { unit rate }(\text { tariff }) \\
& =0.0018 \times 2.18 \text { cen } \\
& =0.392 \text { cents }
\end{aligned}
$$

Int J Pow Elec \& Dri Syst Vol. 11, No. 1, Mar 2020 : $425-432$ 
Total bill in Ringgit $=$ RM 0.39

by Table 3 .

For hardware experimental test, result for unit and bill are 0.0188 and 0.388 cents ringgit as shown

Table 3. Comparison experimental test and calculation result

\begin{tabular}{ccc}
\hline Type of Comparison & Experimental & Calculation \\
\hline Total Pulses (Led blinking) & 9 & 9 \\
Unit & 0.0183 & 0.018 \\
Total bill & RM 0.0388 & RM 0.39 \\
\hline
\end{tabular}

Based on the data in the table above, there appears to be a slight difference between the data from the experiment and the results of the calculation. The difference is $1.7 \%$ greater than the unit obtained from the experiment than the calculation, then the total bill from the calculation of $0.5 \%$ is greater than the total bill obtained from the experiment. This small difference may occur due to the decimal rounding done in the calculation.

\section{CONCLUSION}

Based on the experimental test of the device develop, it able to work well. The coin $\mathrm{kWh}$ meter can accept 10 cents, 20 cents, 50 cents and 1 Ringgit coins. From the 40 trials for each type of coin, only one false $(2.5 \%)$ occurs in the 20 cent coin type. This means that coin acceptors have good performance. The unit obtained from the experiment is $1.7 \%$ greater than from the calculation, then the total bill from the calculation is $0.5 \%$ greater than the total bill obtained from the experiment. These two differences are smallest and can accept.

\section{ACKNOWLEDGEMENTS}

The authors would like to thanks to the Registrar Office of Universiti Tun Hussein Onn Malaysia for their support this paper publication.

\section{REFERENCES}

[1] Unit Homestay Bahagian Pembangunan Industri, "Statistik Terkini Program", Kementeri Pelancongan dan Kebudayaan Malaysia, April 2017.

[2] N. H. M. Saleh., "Homestay untuk ekonomi dan komuniti," Utusan online 15 Julai 2016, 5.10 pm, Available: http://www.utusan.com.my/rencana/utama/homestay-untuk-ekonomi-dan-komuniti-1.350468. 15 July 2016.

[3] J. Kasuma, et al., "Tourist perception towards homestay businesses: Sabah experience," Journal of Scientific Research and Development, vol. 3, no. 2, pp. 7-12. 2016.

[4] S. M. Nor \& K. W. Awang, "Challenges Faced by Operators to Sustain Homestay Businesses in Selangor Malaysia," International Journal of Innovation in Social Sciences, vol. 2, no. 1, pp. 1-11, 2017.

[5] A. N. A. Halim., "Homestay: earning extra income," New Strait Time, March 8, 2018 (Online), Available: https://www.nst.com.my/property/ 2018/03/342954/homestay-earning-extra-income, March 8, 2018.

[6] C.S Tan, et al., "Electricity energy outlook in Malaysia," presented at 4th International Conference on Energy and Environment 2013 (ICEE 2013), March 5-6, 2013.

[7] B. Dikhanbaev, et al., "Energy-saving method for technogenic waste processing," PLoS ONE, vol. 12, no. 12, Dec 2017.

[8] S. T. Teong-Jin, et al., "What are the Attractiveness Aspects that Influence Customer Loyalty to Homestays? A Study in Taiwan," Jurnal Pengurusan, vol. 48, pp. 201-218, Dec. 2016.

[9] Victoria State Government, "Energy conservation: 10 ways to save energy," From htps://www.victorianenergysaver.vic.gov.au/ save-energy-and-money/top-10-ways-to-save-on-energy-bills, Jul 6, 2018.

[10] G. V. Iana \& C. Monea, "Coin recognition system based on a neural network," in the $20146^{\text {th }}$ International Conference on Electronics, Computers and Artificial Intelligent (ECAI), Oct. 23-25, 2014.

[11] C. Gunjan, et al., "Automatic gadget charger using coin detection", Presented at $1^{\text {st }}$ International Conference on Next Generation Computing Technologies (NGCT-2015), Sept 4-5, 2015.

[12] M. Aditi, et al., "Coin operated water dispenser," International Research Journal of Engineering and Technology (IRJET), vol. 4, no. 5, pp. 356-359, May 2017.

[13] T. Agarwal., "Introduction on energy meter: different types of energy meters," EDGEFX Technologies Pvt Ltd (Online). Available: https://www.edgefx.in/introduction-on-energy-meter-different-types-of-energy-meters/, March 2016. 
[14] S. Barrett., "Arduino microcontroller processing for everyone," $3^{\text {th }}$ Edition, Morgan \& Claypool Publishers, 2013.J. L. Rojas-Renteria, et al., "An Electrical Energy Consumption Monitoring and Forecasting System", Engineering, Technology \& Applied Science Research, vol. 6, no. 5, pp. 1130-1132, 2016.

[15] E. Vinagre, et al., "Electrical energy consumption forcast using external facility data", in 2015 IEEE Symposium Forecast Using External Facility Data, pp. 659-664, 7-10 Dec., 2015.

[16] Tenaga Nasional Berhad, "Electricity Supply Application Handbook", $3^{\text {th }}$ Edition, Nur Johan Sdn Bhd, 2011.

[17] Suruhanjaya Tenaga, "Towards a word class energy sector", Energy Malaysia, vol. 7, 2016.

[18] I. Sato, Diptarama, at al., "Analysis of laboratories electrical energy consumption by visualization for saving electrical energy," International Journal of Institutional Research and Management, vol. 1, no. 1, pp. 53-66, 2017.

[19] "Way to reduce electricity consumption at home", The Star online, Wednesday, 26 Feb 2014, 1:07 pm, Available: https://www.thestar.com.my/news/nation/2014/02/26/reducing-electricity-consumption-at-home/

[20] M. R. Buncha, et al., "Local homestay operator dillema: business intention or family intention," International Journal of Business and Management, vol. 1, no. 2, pp. 112-116, 2017.

[21] Public Outreach and Civil Society Division, "ASEAN homestay standard," Association of Southeast Asian Nations (ASEAN), 2016.

[22] N. M Ayob \& T. Masron, "Issues on safety and security: New challenging to Malaysia tourism industry," in $S H W$ Web Conference, vol. 12, pp. 1-10, 2014.

[23] A. Sarwar., "Medical tourism in Malaysia: Prospect and challenges," Iranian Journal of Public Health, vol. 4, no. 8, pp. 795-805, Aug. 2013.

[24] E. M. Ugleva, et al., "Intelligent power consumption management system," IERI Procedia, vol. 4, pp. 117-122, 2014.

[25] R. Karoly \& C. D. Dumitru, "Management of a power system based on renewable energy," Procedia Technology, vol. 12, pp. 693-697, 2014.

\section{BIOGRAPHIES OF AUTHORS}
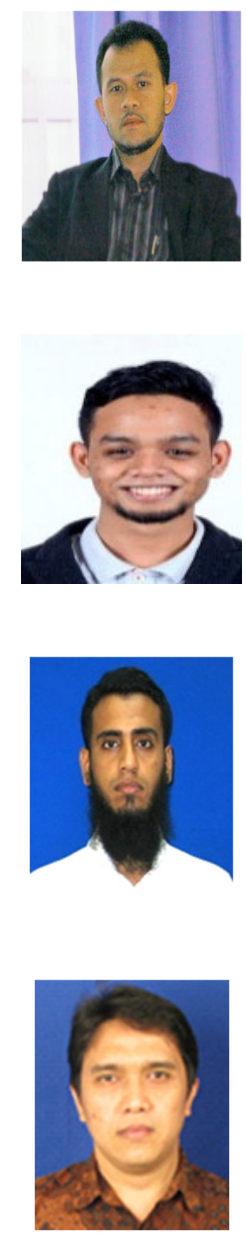

Dirman Hanafi Dirman Hanafi received the Ph.D. degree in Mechatronic Engineering (specialized in Control and Instrumentation Engineering) from the Department of Control and Robotic Engineering, Faculty of Electrical Engineering, Universiti Teknologi Malaysia (UTM), Malaysia in 2006.

Currently he is working at University Tun Hussein Onn Malaysia (UTHM) as an Associate Professor and researcher. His research interests are in the field of System Identification and Intelligent Control for applications in vehicle suspension systems, robotics, and electrical power plants.

Kamal Khairi Kamaruddin received the B.Sc. degree in Mechatronic and Robotic Engineering from Faculty of Electrical and Electronic Engineering, Universiti Tun Hussein Onn Malaysia (UTHM), Malaysia in 2018

Hisyam Abdul Rahman received the Ph.D. degree in Mechatronic Engineering (specialized in Biomedical Engineering) from the Department of Control and Robotic Engineering, Faculty of Electrical Engineering, Universiti Teknologi Malaysia (UTM), Malaysia in 2016.

Currently he is working at University Tun Hussein Onn Malaysia (UTHM) as a lecturer and researcher. His research interest are in robotic and rehabilitation after stroke injury.

Yudhi Gunardi currently pursuing his Ph.D.degree in Mechatronic Engineering (specialized in Robotic Control Engineering) in the Department of Mechatronic and Robotic Engineering, Faculty of Electrical and Electronic Engineering, Universiti Tun Hussein Onn Malaysia (UTHM).

Currently he is working at Universitas Mercu Buana as a lecturer and researcher. His research interest is control system in robotic application. 